\title{
The bargaining theory of war and peace
}

\section{Charles H. Anderton}

Charles H. Anderton is Professor of Economics, College of the Holy Cross, Worcester, MA, USA. He may be reached at canderto@holycross.edu.

\section{Abstract}

The bargaining theory of war and peace has emerged as an important research framework in the social sciences for understanding why wars occur and why opportunities for peace sometimes fail. Close to a dozen distinct "rationalist" sources of war have been theoretically modeled in the bargaining literature, empirical studies of war and peace are increasingly drawing upon bargaining models for theoretical guidance, and "nonrationalist" sources of war based on insights from psychology and sociology can be incorporated into the theory. This article briefly surveys key elements and results of the bargaining theory of war and it emphasizes the untapped potential for the framework to serve as a theory of peace in both research and teaching.

$\mathrm{T}$ his essay briefly introduces the work of Walter Isard, founder of both peace science and peace economics, and then elaborates more broadly on the bargaining theory of war and peace.

\section{Peace economics and the rationality of war}

Walter Isard is considered by many, including myself, as the founder of peace science, a multidisciplinary approach to studying violent conflicts and how they can be managed or resolved nonviolently. Isard is also the founder of peace economics, which is also multidisciplinary but with a more focused study of violent conflict and peace using the tools and concepts of economics. According to Isard (1994, p. 9), peace economics

“... is generally concerned with: (1) resolution, management or reduction of conflict in the economic sphere ...; (2) the use of economic measures and policy to cope with and control conflicts ...; and (3) the impact of conflict on the economic behavior and welfare of firms, consumer organizations, government and society. Central to the field are: analyses of conflicts among nations, regions and other communities ...; measures to control (deescalate) arms races and achieve reduction in military expenditures and weaponry; and programs and policies to utilize resources thus released for more constructive purposes ... Behaving units are taken to engage in appropriative ... as well as productive activities, with war often viewed as a rational, purposeful choice of decision makers" (my emphasis).

The final sentence in Isard's statement points to the principle that war can be a rational choice. This principle is often misunderstood outside the peace economics community, and sometimes within. I have heard on occasion, even at peace economics conference sessions, an argument for the irrationality of war that goes as follows: Whatever outcome the combatants arrive at once the war is over, they could have arrived at that outcome without the war and thus without all of the costs of war. Hence war is irrational. In what follows, I claim that this argument has been theoretically refuted by the bargaining theory of war. More importantly, I argue that the bargaining theory of war can be fruitfully incorporated by peace economists (and others) into their teaching, thinking, and research about war and peace. Finally, I claim that although the bargaining theory is a theory of war, it is also and at the same time a theory of peace. That is, the bargaining theory framework can help us to understand why violent conflicts happen and why peace or nonviolent resolutions to conflicts transpire.

\section{The bargaining theory of war: Essential foundations Overview}

Formal models of the bargaining theory of war began to appear in earnest in the mid to late 1990s and into the 2000s following the work of Fearon (1995). Such models are top-down or macro-oriented in that they focus on the critical leaders of two or more sides who are bargaining over a disputed item (e.g., territory). The models are designed to identify conditions in which at least one side in the dispute finds it beneficial, net of costs, to initiate war. Such conditions for war identified by bargaining theory have come to be known as rationalist sources of war. It is important to note that the vast literature on conflict management procedures, negotiation principles, methods for getting to "yes," and so on is distinct from the bargaining 
theory of war literature even though the former involves much bargaining analysis. What the bargaining theory of war aims to identify are conditions in which no amount of scientific and artful bargaining techniques among the disputing players themselves will be able to prevent war.

\section{Two propositions and a key question}

The bargaining theory of war is built upon two deceptively simple propositions and a key question.

Proposition 1: War is costly.

The costs of war include the extra diversion of scarce resources to weapons and soldiering for fighting; the destruction of people and property; the disruption of economic (and other) activities such as international trade, production, and local markets; and the displacement of people in the form of internally displaced persons (IDPs) and refugees. Proposition 1 seems obvious. After all, the purpose of war from the perspectives of the leaders and commanders prosecuting war is to inflict costs on rivals. War is costly because it is intentionally designed to be costly.

Proposition 2: Peaceful resolution offers potential mutual gains to the would-be combatants in the avoidance of the costs of war.

Players who could become involved in war, whether they be nations, rebel groups, or other nonstate actors, have the potential to gain from war avoidance by substituting peaceful resolution for war. By avoiding the costs of war, the players would have a "pie" (in the form of avoided war costs), which they could divide among themselves to improve their wellbeing. Peace seems like a bargain!

Key question: Given propositions 1 and 2, why does war occur?

\section{The economic nature of the theory}

Before addressing the key question of the bargaining theory of war, consider the thoroughgoing economic nature of the theory. It includes the costs of war and the potential mutual gains from peace. Economists are always thinking about costs, but even more so about mutual gains. Economists assiduously seek out opportunities for mutual gains. When mutual gains are not taken advantage of and are, in a sense, left on the table, economists are baffled and demand an explanation. But wars do occur, i.e., the potential mutual gains from peace are sometimes left on the table and they are often left there as a result of the purposeful
The essay argues that the bargaining theory of war also is a theory of peace. War denotes the failure of bargaining; peace its success. The bargaining theory framework can help us to understand why, despite bargaining, violent conflicts happen and why peace or nonviolent resolutions to conflicts transpire.

choices of decisionmakers. But sometimes (and actually quite often) the mutual gains from peace are chosen. Hence, the bargaining theory has at its center the notion that both war and peace are chosen.

\section{Sources of war in bargaining theory}

Rationalist sources of war

For bargaining theory, what are the sources of war? The first column of Table 1 provides an answer to this question by identifying eight rationalist sources of war. What is meant by a rationalist source of war is that the decisionmaker (or decisionmakers) who initiates war believes s/he will achieve a gain in wellbeing relative to peacefully settling. Of course, ex post, the decisionmaker's balance sheet may show a loss relative to the outcome that would have occurred under peace. This could occur in the case of the first rationalist source of war listed in column 1 of Table 1, incomplete information. The decisionmaker may simply have erroneous information heading into war and only come to appreciate the true costs of war and the gains that could have accrued under peace through the harsh learning environment of war.

To appreciate the deeper implications for war offered by the bargaining theory, suppose the decisionmakers on two disputing sides (and there could be three or more sides) have complete information. With mistakes ruled out by assumption, it would seem that peace would prevail. After all, the two sides will have complete information about the costs of war and thus they will know that avoidance of the costs of war is a "pie" for them to divide up to achieve a mutual gain from avoiding war. It would seem that there would be no (rational) way for them to miss such a bargain. Unfortunately, this is not necessarily the case. A key principle of the bargaining theory of war is that (for the case of two sides) it takes both sides to achieve peace but only one side to initiate war. This principle serves as a "nail in the coffin" of the oft-heard idea that war must be irrational because whatever the outcome from war is, the players could have done better by avoiding war. This idea is an example of the fallacy of composition. It is true that the aggregate of players would have more "pie" to work with by avoiding war, but it does not follow that each individual player would gain from peace relative to war. It could be that one of the players, in a model in which both players know everything, can gain from war. This is an important and unsettling implication of the 
bargaining theory of war.

The next seven items listed in column 1 of Table 1 are additional reasons why a player can gain from war relative to peace, despite the costliness of war. Consider the case of preemptive geography and military technologies. In such a setting, each side perceives (correctly under complete information) that whichever side launches war first will do better than the other side in the war. Assume the preemptive setting is quite "strong," i.e., whoever launches first will do much better than the other. Formal models in the bargaining theory literature have demonstrated that if the preemptive advantage is sufficiently large relative to the costs of war, a mutually beneficial bargain for peace is not available to the two sides under such conditions. Without a change in these conditions, perhaps fostered by outside help, peace fails. In short, war is "rational."

Consider next the case of preventive war, again under the assumption of two disputants. Preventive war centers on the question, might a war today be a "price" worth paying in order to prevent the emergence of a draconian future? For example, consider the case of a government (player A) and a rebel group (player B). Assume peaceful settlement between A and B in the present would confer new status and acceptability to B within the nation such that group B's power would grow relative to A. Given the power shift, potential future bargaining between the two players over a disputed item would be much more favorable to B. Player A could conclude that it is "cheaper" to fight B today and keep it weak than to face a much more costly contest with $\mathrm{B}$ in the future. Formal models in the bargaining theory literature have shown that if the future shift in power is sufficiently large relative to the costs of war, the potential gain available under peace is too small to induce player A to prefer peace to the gain that can be achieved from initiating preventive war. Once again, a mutually beneficial bargain for peace is not available to the two sides under such conditions. Without a change in these conditions, perhaps again fostered by outside help, peace fails and, again, war is "rational."

The other rationalist sources for war listed in column 1 of Table 1 have also been demonstrated in formal models within the bargaining theory literature. Indivisibility pertains when two or more actors have preferences for a disputed item (often sacred territory, but also other "terrains" including identity and ideology) that are inherently incompatible and cannot be compromised across the actors. Political bias covers a potentially wide array of reasons why the key political leader (or leaders) within a state or nonstate group could gain from war even though the war would be a net loss for the people that the leaders claim to represent. The next item in column 1 of Table 1 - the incentive to eliminate a persistent rival - is a distinctly economic rationale for war. Again consider two sides and assume they have a long-standing rivalry. The rivalry is expensive each year as each side develops costly armaments vis-à-vis the other side. It can be "cost effective," if the opportunity presents itself, for one side to launch war and completely destroy the other side. With the other side eliminated, the yearly savings from not having to contest the rival can be substantial. The next item-concern for reputation - has been a long-recognized source of war. As just one example, a government (player A) may choose to initiate a costly war against rebel group $B$, even if a mutual gain from peace within the dyad itself is feasible. Why? Such a "price" might be worth paying by $\mathrm{A}$ in order to deter the emergence of potential rebel groups $\mathrm{C}, \mathrm{D}$, and $\mathrm{E}$. The last item in column 1 of Table 1 - war as means of national unification-would occur, for example, when a key leader of a state initiates interstate war in order to reduce costly internal disunity within the state and thus make the state (and leader) better off, on net.

The first column of Table 1 lists eight "rationalist" sources of war. Much more could be said about the eight, but let me instead make five general remarks about them. First, the eight have been formally modeled. This is important because the models demonstrate in a rigorous and disturbingly inescapable manner how the potential gain from peace will be missed and war chosen instead. Second, new formally substantiated rationalist sources of violent conflict will be discovered in the years ahead (indeed, there are likely others already that I have neglected to include in Table 1). Such work is analogous to the discovery of new subatomic particles in theoretical physics. Third, within some of the eight, there are further variants that could be classified as distinct rationalist sources of war. For example, "political bias" covers discrepancies between the interests of one or a small group of leaders that make the decision for war or peace and the interests of the broader population that the leaders claim to represent. Hence, war as political diversion and war as an opportunity for private gain are just two subcomponents of "political bias." Fourth, any one of the eight sources of violence acting alone has the potential to lead to war, but most wars likely have multiple such elements in play. Hence, there are, unfortunately, many paths to war implied by column 1 of Table 1. Finally, numerous empirical and case studies have emerged in the last two decades in which bargaining theory has been leveraged to generate interesting, insightful, empirically supported, and policy-relevant hypotheses about war and peace.

\section{Nonrationalist sources of war}

In addition to the rationalist aspects of war, scholars focused on war and peace also consider so-called nonrational sources of 
war. Column 2 of Table 1 provides two examples of nonrationalist sources of war. First, at the intersection of economics and psychology, the field of behavioral economics has provided evidence from laboratory and field experiments that people's decisions are often affected in significant ways by reference dependence and loss aversion. Reference dependence is the idea that one's current holding of an item, say land, wealth, or political power, causes one to become accustomed to such a holding. Such an accustoming means that one's loss in utility from suddenly having less of the item will be doubly painful: Not only will the person have less of the item (which is a utility loss), but the person's holding will now fall short of the accustomed level (another utility loss). Given losses in an item relative to a reference point, laboratory and field evidence in behavioral economics has also discovered that people tend to magnify the value of a loss of an item relative to the increase in value accruing from an equivalent gain in the item.

It seems reasonable to believe that reference dependence and loss aversion would be relevant in political leaders' calculations regarding war and peace. Such a prospect is probably not good news regarding the risk of violent conflict and hopes for peace. Consider, for example, a potential shift in power in favor of player B and against player A and the risk of preventive war. Presumably A has become accustomed to the current balance of power, i.e., it is A's reference point. A shift in power against $\mathrm{A}$ is a loss, which loss aversion would tend to magnify in importance in A's evaluations of war and peace. If the potential shift in power is moderate and insufficient to lead A to rationally initiate preventive war, the magnification of loss suggested by reference dependence and loss aversion might be sufficient to kick the case over the line into war. Hence, the combination of a rationalist source of war and a psychological inflammation of that source can cause the bargain of peace to fail.

A second nonrationalist source of war is shown in column 2 of Table 1. It occurs at the intersection of economics and sociology in regard to the field of the economics of identity. It is obvious that people care about (gain utility and disutility) from the groups that they belong to and do not belong to and the social contexts in which they live. It is also clear that the twenty-first century is shaping up as a period in which identity and ideological "terrain" will be much contested across and within states, perhaps as much as classic, geographic territory and its resources (land, oil, borders, etc.) are contested. The economics of identity field demonstrates that actors, including of course political leaders, invest resources to strengthen group identity and ideology and, at times, to undermine and even destroy the identity of other groups. Such ideas connect to the notion of malevolent preferences in the bargaining theory of war as a potential source of war. "Us vs. Them" investments in identity by, say, two groups, will lead to preferences in which each side gains utility when they acquire more of a disputed item, but they will also gain utility when their rival obtains less of the disputed item. An example of a malevolent preference would be me being happier if I gained \$1 and you lost a \$1 than if I just gained \$1 myself. Within the bargaining theory of war, malevolence has been formally shown to narrow and sometimes eliminate the mutual gain available to the players under peace.

Before moving to the peace side of bargaining theory, two final points should be noted about the so-called rationalist and nonrationalist sources of war in columns 1 and 2 of Table 1 . First, both sources of war can be theoretically integrated within the bargaining model. Hence, the two categories are not in competition with one another for "allegiance" by social and behavioral scientists. We have a both/and, not an either/or, dichotomy. Both matter, and future work should press forward with their integration in formal theoretical models. Second, even if cognitive and identity-related "glitches" are not in play, there are still numerous rationalist reasons why wars will occur. And if somehow all the rationalist sources of war could be inoculated against, there are psychological and social issues associated with the human mind that could still cause wars to break out. These are disconcerting results!

\section{The bargaining theory of peace: Essential foundations The drama of peace}

Disconcerting, yes, but certainly not hopeless. One of the great prospects of bargaining theory is its other side: peace. An underdeveloped feature of the bargaining theory of war is that war (or, more generally, violent conflict) and peace are not separate silos. This is why the title of this essay is "The Bargaining Theory of War and Peace" and not the title used virtually everywhere else in the literature, namely, "The Bargaining Theory of War." The two-sided drama of whether disputes between parties will turn violent or be managed with nonviolent means is integrated in the bargaining theory of war. This "integral-ness" of war and peace is quite clear in Thomas Schelling's classic work, The Strategy of Conflict (1960). Schelling first indicates the essential bargaining nature of potential or actual violent conflict: "To study the strategy of conflict is to take the view that most conflict situations are essentially bargaining situations" (p. 5, his emphasis). Then Schelling indicates that in the bargaining over war and peace, "the possibility of mutual accommodation is as important and dramatic as the element of conflict" (p. 5). This is a remarkable statement. Choosing peace is just as dramatic as choosing war! The potentials for war and peace are coupled in the bargaining 
Table 1: Selected sources of war and peace in bargaining theory

Sources of war

Rationalist

Incomplete information

Preemptive geography and military technology

Preventive war
Indivisibilities
Political bias
Incentive to eliminate a
persistent rival

Reputation

War as means of national unification
Reference dependence and loss aversion

Malevolent preferences rooted in identity, culture, and history
Nonrationalist

Rationalist

More complete information (e.g., mediation to close expectations gap)

Reconfigurations of weaponry to reduce first-strike advantages (e.g., qualitative arms control)

Prevention of or security guarantees leading into substantial power shifts

Intertemporal sharing arrangements; arbitration with third-party enforcement

Democratization

Third-party incentives (carrots and sticks) to create net gain for peace; de-escalation of enduring rivalry among the players

Third-party incentives (carrots and sticks) to create a net gain for peace

Third-party incentives (carrots and sticks) to create a net gain for peace

\author{
Mediation to provide security \\ guarantees and "slow \\ thinking" \\ Cultural and educational \\ exchanges; trade and FDI; \\ diverse hiring practices of \\ firms; counters to hate radio \\ and other forms of anti-group \\ propaganda
}

Nonrationalist 
points to what policies and programs designed to foster peace need to do: They need to overcome or inoculate against the rationalist and nonrationalist sources of war. Examples of such inoculations for peace are provided in columns 3 and 4 of Table 1. In addition to diminishing specific rationalist and nonrationalist sources of war, formal bargaining models point to general conditions that foster peace including productive economies, which raise settlement opportunities and the opportunity cost of war; neutral or even benevolent preferences, which create or expand the range of feasible peaceful settlements; and proactive and early third-party help, which can, potentially, lead to many benefits including overcoming commitment problems, subsidizing peaceful settlement opportunities, and (as already noted) dampening inflamed rationalist and nonrationalist sources of violence.

\section{Conclusions}

Peace economists can use the bargaining theory of war and peace as a diagnostic tool, an intellectual X-ray. The theory allows us to diagnose why wars begin (war onset), why wars fail to end (war termination), why wars restart (war recurrence), why wars spread (geographically, and to other players), why wars get more serious (war intensity), and what policies and programs can help substitute peace for such outcomes. The bargaining theory of war and peace can also be used to model and theorize about degrees of peace that emerge (and can be cultivated) well short of war including durable peace and stable peace and how such outcomes can be invested in and maintained over time and geographic space (and maybe even over identity and ideological space). Furthermore, just like bargaining theory is used to generate empirically testable hypotheses about war, the theory can be used to generate empirically testable hypotheses about peace (much empirical work has occurred for the former, but very little for the latter). In addition, bargaining theory has the potential to generate a rich menu of policy ideas and tools for maintaining peace where it is present and creating peace where it is absent. Finally, and related to the points already made, there are substantial future opportunities to leverage bargaining theory to study, theoretically, empirically, and with case studies, why peace happens (the "causes" of peace).

Suggestions for further reading

Anderton, C.H. and J.R. Carter. 2011. "A Bargaining Theory Perspective on War," pp. 29-51 in D.L. Braddon and K. Hartley, eds. Handbook on the Economics of Conflict. Cheltenham, UK: Edward Elgar. https://doi.org/10.4337/9780857930347.00008

Fearon, J.D. 1995. "Rationalist Explanations for War." International Organization. Vol. 49, No. 3, pp. 379-414.
https://doi.org/10.1017/S0020818300033324

Isard, W. 1994. "Peace Economics: A Topical Perspective." Peace Economics, Peace Science and Public Policy. Vol. 1, No. 2, pp. 9-11.

Mitchell, S.M. 2017. "Dangerous Bargains with the Devil? Incorporating New Approaches in Peace Science for the Study of War." Conflict Management and Peace Science. Vol. 34, No. 1, pp. 98-116. https://doi.org/10.1177/0738894216667621

Sambanis, N., S. Skaperdas, and W. Wohlforth. 2015. "Nation-Building through War." American Political Science Review. Vol. 109, No. 2, pp. 279-296. https://doi.org/10.1017/S0003055415000088

Schelling, T.C. 1960. The Strategy of Conflict. Cambridge, MA: Harvard University Press. 